\title{
Social Factors Influencing Substance and Drug Abuse in Universities in Machakos County, Kenya
}

\author{
Patricia Makau Elizabeth Muema Milcah.W.Mutuku \\ Machakos University Department of Educational Psychology
}

\begin{abstract}
The intention of this study was to investigate social factors influencing substance and drug abuse in universities Machakos County, Kenya. The survey study was carried out in Universities in Machakos town. The study was guided by the following objectives: to find out social factors influencing substance and drug abuse in Universities Machakos town and Establish the relationship between gender and drug abuse. The target population comprised of (10,000) students. A sample of (110) respondents was drawn from 5 University college /campuses. Stratified sampling techniques were used to sample (40) female and (70) male students. The research utilized questionnaires as the research instruments. The research instruments were modified after pilot study. The validity and reliability of instruments was established by piloting the instruments in pilot institutions in Machakos University College and Scott university. The reliability of research instrument was determined through the split- half method. The reliability index for the research instrument was 0.78 . Qualitative data collected was analyzed descriptively using frequencies and percentages. The main findings of the study were: the prevalence of drug abuse according to gender was male $(62.7 \%)$ and female $(37.3 \%)$ and according to university. The social factors contributing drug abuse was peer pressure had (78.2\%) and parental and environmental factors $(20 \%)$. The research also revealed that commonly abused was alcohol with (78\%), followed by cigarette $(58.5 \%)$, followed by illicit brews $(50 \%)$, miraa (40\%), bhang (21\%), wines and spirits (15\%), finally the least abused drugs were heroin and cocaine with less than 1 percent. On the relationship between gender and drug abuse, the findings reveled that male students three times likely to abuse drugs more than female students. The study made the following recommendations: Government should put in place measures of limiting easy access to drug, Interventions progammes should be designed to halt drug abuse among those who are already abusing drugs and Rehabilitate those who show signs of addiction and finally guidance and counseling strengthened should be strengthened in institutions of learning and especially peer counseling
\end{abstract}

DOI: $10.7176 /$ RHSS/9-20-06

Publication date:October $31^{\text {st }} 2019$

\subsection{Introduction}

Globally the World health organization (WHO) estimates that 155 to 250 million people $(3.5 \%-5.7 \%)$ of population aged $(15-64)$ uses illicit substances at least once (National Agency for the Campaign against Drug Abuse (NACADA), 2011). The same report consequently estimates that there are between 16 and 38 million people experiencing drug related problems in the world. While drug use has stabilized in the developed world there are signs of an increase in drug use and abuse in the developing countries. About 200,000,000 people worldwide abuse drugs: in United States $40 \%$ of students abuse drugs, in Asia 48.9 of University students use drugs among them, $24 \%$ are first years while 75.6 are final years, in South Africa $52 \%$ of University students take drugs(Ministry of education science and technology (MOEST), 2009).

While drug use may start as a seemingly harmless and voluntary act, with time it can develop into a compulsive and unstoppable habit. In the beginning, drug use minimizes emotional and physical pain. As prolonged drug use continues, it can develop into drug addiction, severely

impacting an individual's brain chemistry. When the brain begins to signal an intense physical need to continue the use of drugs, what once was recreational use becomes an urge that controls one's life (National Institutes for Alcohol Abuse and Alcoholism (NIAAA), 2009).

According to report by NACADA (2007) $13.0 \%$ of Kenya population aged between 16 and 65 currently consuming Alcohol, Miraa (5.5\%), Bhangs (1\%), Cocaine (0.2\%), and Heroin (0.1\%)in the country. Drug abuse scourge in Kenya has taken its toll on the society largely out of the fact that not many people treated the various substances as the source of the serious health afflictions. Lack of awareness, fanned by unavailability of accurate information on the adverse consequences of indulgence habits has left the problem of drugs and substance abuse to penetrate(Simonyi, 2011).NACADA (2004) confirmed that a large number of students in Kenya across all age groups have been exposed to alcohol, tobacco, khart (miraa), glue sniffing, bhang, and even hard drugs.

Lonah (2013) indicated that there are millions of youth wasted by drugs. Statistics showing high rates of alcohol and drug abuse (ADA) among the youth have forced the Government to take drastic action on the peddlers. President Uhuru Kenyatta, on $5^{\text {th }}$ July 2013 during the opening of the second national conference on alcohol and drug abuse (ADA) in Moi International Sports Centre in Kasarani Nairobi, directed police to arrest drug traffickers and deport foreigners involved in the illegal trade. The President also called on (NACADA) to formulate measures 
to curb drug abuse. He directed the National Treasury to allocate more resources for prevention and control of alcohol and drug abuse and seek innovative ways of securing funding to increase NACADA'S resource base in the fight against substance abuse. NACADA (2010) during the conference themed "Youth and Drugs, A call for Action", sought to engage more stakeholders, including faith-based and youth organizations in the war against drugs. Presentations made by the participants and experts during the four day conference revealed shocking details of millions of youth abusing alcohol and drugs (Achola,2013). NACADA director pointed out that alcohol consumption accounted for 4 million users, tobacco 2.7 million while more than 700,000 people abused drugs. He said this has the potential to negate all the health, socio-economic and political gains if nothing is done urgently (Achola,2013).

\section{Statement of the Problem}

Studies done in Kenya concluded that drug abuse is an existing phenomenon among the youth. University students are at greater risk of indulging in drug and substance abuse activities whose consequences they least understands. The problem of drug and substance abuse has pervaded the education and training systems. A week hardly passes without leaders of all walks of life complaining of drug abuse among the youth. Politicians, Church leaders and even business community have constantly cautioned the youth against drug abuse. The use and abuse of drugs in these crucial years of learning and training is worrying trend in our institution of higher learning. These are the years during which youth acquire social, emotional, self - concept and aptitude skills. The skills acquired at this stage enable young people to grow into meaningful, self-fulfilling individuals in the society. The beginning of the abuse of drug at this period is a sign of unsuccessful youth and is a mild way in the development of a deviant lifestyle. Universities draw their students from secondary schools. This suggests that it would be possible for students who abused drugs in their secondary school life to carry this habit to Universities. While others get influenced by their peers, others get into drugs due boredom and new found freedoms; considering that university life is not as strict and routinely as secondary schools.

Drug abuse is widely spread among the youth between 14 and 28 years and most of these youths are nonstudents. There is greater possibility for University students to be lured into drug abuse because they greatly interact with non-students in various ways. This possibility is very real bearing in mind that fresh grandaunts from secondary schools are not immediately admitted in Universities and the period they spend in waiting for admission presents a trying moment. Young people who persistently abuse substances often experience an array of problems, including academic difficulties, health-related problems (including mental health), poor peer relationships, and involvement with the juvenile justice system. Additionally, there are consequences for family members, the community, and the entire society. It's important to note that youth in Kenya constitutes of $50 \%$ of total population and government spends a lot of resources on the education sector, due to prevalence problem therefore several researchers previously have undertaken studies to identify factors influencing drug abuse in secondary schools.

A study by NACADA(2010) on Drug abuse among Youth revealed that there was very high non- response to interviews by students in Universities; $47 \%$ in Private University and $30.7 \%$ in public University, it recommended for further investigation, compared to high response to primary schools $(100 \%)$,Secondary schools (77.9\%),Machakos town is a home of various Universities i.e. Machakos University College, Scott Christian University, Nazarene University Campus, Seku University Campus and St. Paul University campus. The researcher intends to investigate social and contextual factors influencing substance and drug abuse in University students in Machakos town. The primary objective of the current study therefore is to identity social and contextual factors influencing drug and substance abuse in Universities in Machakos town, Machakos County.

\subsection{Objective of the Study}

The study will be guided by the following objectives:-

i. To find out social factors influencing substance and drug abuse in Universities Machakos town.

ii. Establish the relationship between gender and drug abuse

\section{RESEARCH METHODOLOGY}

\subsection{Introduction}

This chapter describes methods that will be used in the study in order to realize the set objectivities. It contains the researcher's design, location of the study, target population, sampling techniques, research instruments, pilot study, validity, reliability, data collection techniques, data analysis and ethical considerations.

\subsection{Research Design}

The research will be conducted using descriptive study which will employ survey design. The descriptive statistics includes multiple variables for analysis (Kothari, 1985). The variables were substance and drug abuse as depended variable and peer pressure, parental and environmental influence, as independent variables. Survey design has an advantage over other designs in that it enhances collection of data of a large group (Fraenkel\&Wallen, 2000) 


\subsection{Research Variables}

Dependent variable in this study was the substance and drug abuse and independent variables in this study were peer pressure, parental and environmental influence.

\subsection{Location of the Study}

The study was carried out in Machakos Town, which constitutes; Machakos University college, Seku, University campus, Nazarene University campus, St.Paul University campus and Scott University. The students from these Universities were picked during the study. The researcher had chosen this location because Machakos is a fast growing county with Machakos town being its head- quarters; hence higher education is also growing very fast.

\subsection{Target Population}

The study population comprised of young people aged between 16 to 30 years. This age bracket was chosen because it is likely to be found in institutions of higher learning. University students were chosen because they comprise majority of the youth attending Universities in Machakos town. Machakos town has five Universities campuses/college, comprising of population of about 10,000 students. There are approximately 5,200 males and 4,800 females. (Source: Individual University admission records).

\subsection{Sampling Techniques and Sample Size}

According to Kombo\& Tromp (2006) sampling is suitable in selecting a number of individual from a population. The selected group contained elements which were a representative of the characteristics found in the entire population.

\subsubsection{Sampling Techniques}

The study used stratified sampling to select the students. It was used to ensure that certain subgroups in the population are represented in the sample (Kothari, 1985).

Stratified sampling also ensures that any key characteristics of the individual in the population are included in the sample proportion in the sample (Mugenda\& Mugenda 1999). Each stratum was further divided into two strata. The sampled University campus/college was selected by simple random sampling which gave an equal chance of inclusion. The sample included more males than females.

\subsubsection{Sample Size}

A sample of 120 students from the four institutions from $2^{\text {nd }}$ and $3^{\text {rd }}$ year students were randomly selected. There were 66 male and 54 female students..

\subsubsection{Research Instruments}

The researcher used the multiple choices and the Likert scale rating system for the questionnaire although there was also some structured and some open - ended questions. A questionnaire was used as all the respondents were literate. The researcher constructed the questionnaire so as to suit the purpose of the study.

\subsubsection{Students Questionnaires}

The questionnaire had 20 items. The types of questions used required yes or no answers, ticking in applicable answers and filling in blank spaces. One question required the student to tick in a scale from a given choice and in another one the student will give his or her opinion. In part A, students were required to give demographic information such as age sex and year of study. In part B they will be required to answer questions on the kinds of drugs they are aware of, whether they use or do not use drugs or even any friend that may be using the drug, in part $\mathrm{C}$ list the factors influencing drug abuse and part D covers Gender and drug abuse.

\subsection{Validity}

In this study content validity of the instrument were tested. Pilot study was used to identify those items that could be misunderstood and such items were modified accordingly, thus increasing face validity (Willinson, 1991).

\subsection{Reliability}

The spearman - Brown formula was used to establish the split-half reliability test of the research instruments. The test was administered once to the respondents. The split half method was selected due to two main reasons, first it is not affected by the intervening variable of manipulation of the subjects since the questions were administered once and then despondences were divided into two equal halves ( $\mathrm{SH}-1$ and $\mathrm{SH}-2$ ) and then correlation coefficient for the two halves was computed. The procedure for split half is as follows:

$$
r=1-6 E(D) 2
$$

$$
\mathrm{N}(\mathrm{N} 2-1)
$$

Where:

$$
\begin{aligned}
& \mathrm{r}=\text { correlation coeffient } \\
& \mathrm{N}=\text { sample }
\end{aligned}
$$




$$
\text { (ii) } \mathrm{SH}=\underline{2 \mathrm{r}} \frac{\begin{array}{l}
\mathrm{S}=\text { summation of score } \\
\mathrm{D}=\text { deviation }
\end{array}}{}
$$

(Where items are doubled)

\section{Source: Spearman brown formula}

Using this approach, a reliability coefficient of 0.73 was obtained for the two halves. According to Gay (1992) a correlation coefficient of 0.7 or above is adequate to indicate that instrument is reliable.

\subsection{Data Collection Technique}

The student questionnaires were administered to the student from the five University campuses /college. Students were informed by their lecturers and they were given two hours to complete filling the questionnaires. This was done at the same time to ensure that no discussion among the respondents will take place.

\subsection{Data Analysis}

The data collected was processed and analyzed by the researcher. The processing plan involved; editing, coding, classification and tabulation of the collected data. During the editing process, the researcher carefully scrutinized the raw data collected from the respondents with a key objective of ensuring that it was accurately, uniformly and completely entered. The edited data was then coded and entered in SPSS computer package for analysis.

\section{CHAPTER FOUR}

This chapter covers data analysis, presentation of the findings and discussion of the study findings.

\section{FINDINGS}

Table 4.3: showing Social factors influencing drugs abuse

\begin{tabular}{|l|r|r|}
\hline Reasons & Frequency & Percentage \\
\hline Peer pressure & 87 & $78.2 \%$ \\
Parental and environmental reasons & 22 & $20 \%$ \\
Others & 2 & $1.8 \%$ \\
TOTAL & 110 & 100.0 \\
\hline
\end{tabular}

\subsubsection{Peer pressure}

Peer pressure had the highest respondent with (78.2\%) as reasons for taking drug among students. In universities students peer group are part of life and culture. Students form peer group depending on a number of factors. First they form peer group based on economic background; those students who are from well to do families interact together and those from low economic background interact together. Secondly students form peer group according to their interest and hobbies such as sports. Thirdly students form peer group depending on age groups; where students are from a particular age group form their own peer group. Fourthly some form peer group according to academic performance; where else those who perform well in class form their own peer groups mainly for discussion on academic issues. Fifth, others form peer groups because they share some vices like truancy, absenteeism and drug abuse (Kisaki, 2012).

Kimiti (2011) agree with Kisaki that students form peer groups based on the tribe and age, they also form peer groups depending on areas or places where they come from such as those from town or rural form their own peer groups. Students also form peer groups depending on their academic performance such that those who perform very well and those who perform very poorly form different peer groups. Also students form peer group because they share vices like truancy, absenteeism, and drug abuse. Many students belong to more than one peer group, for example students belong to peer group that abuse drugs as well as same tribe.

These different peer groups have different expectations, aspirations and characters. Even students who form peer groups because of possessing vices like abuse of drugs would try to influence other innocent students to join their group of vice like drug abuse. Studies done by Kisaki, (2012), Kimiti (2011), and Kimanthi (2003), all have pointed out that peer pressure could make a student abuse drugs in order to fit in a particular peer group. According to these studies, peer pressure leads to student's drugs because of interests and expectations of the peer group.

\subsubsection{The parental and environmental reasons}

The parental and environmental factor which was cited by dozens of students $(20 \%)$ was attributed to lifestyle of their parents. Some parents drink and smoke in the presence of their children. When these children grow up they start experimenting what their parents have been doing. The study established that there was strong positive correlation (.70) between students who abused drugs and their parents who abuse drugs. According to a student, parents were not providing to their children adequate guidance needed. Conger \& Patterson (2010) noted that parents who smoke have a great influence on their children. In cases where both parents smoke, $20 \%$ of girls and 
$22 \%$ of boys become smokers. He added that if an older sibling smokes and the parents too, then the child is 4 times likely to smoke as opposed to when there is model for smoking. Goldstein (2011) added that parents who use or abuse drugs tend to bring out children that find these drugs acceptable. They also added that parental drug abuse was strongly associated with illegal drug use among students. Very few students (1.8\%) gave other factors as a reason for taking drugs.

\subsection{Gender and drug abuse}

Students were asked to state between male and female who were likely to abuse drugs more.

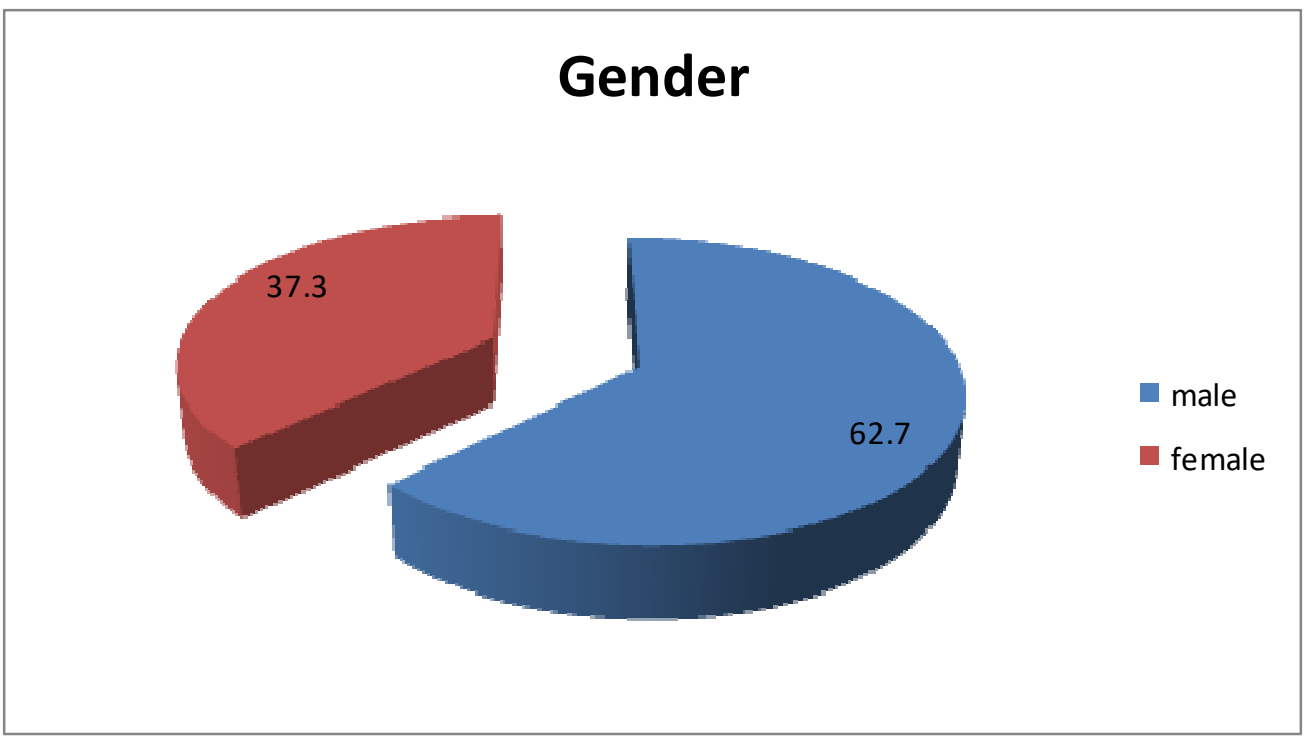

Figure 4.5 pie chart showing relationship between Gender and drug abuse

Figure 4.5 results show that there is link between Gender and drug abuse by University students in Machakos town. The results indicate that males were 1.70 times more likely to abuse drugs as opposed to the female students. This implies that male students in the Universities show significant higher risk to substance and drug abuse than females. This results is with agreement with Kariuki (1988), Wambua (2014), Ruto (2000) and NACADA (2004). All these studies show that there are higher insolences of drug abuse among male students than females. This could be contributed to higher tendency of males being more risk takers, adventurous, curious and culture experiencing among males (Kaguthi, 2006).

This study agrees Johnson (2006) who on his findings revealed that young Kenyan males are likely to experiment with drug and substance than are females. Kenyan males are 3 times more likely to experiment with inhalants, commercial beer, spirits and narcotics than do young females.

\subsection{Commonly abused drugs}

To find out the kinds of drugs commonly abused among University Students in Machakos town; students were asked to indicate the drugs they had taken or were taking, they were also asked to indicate which drugs their colleagues were taking. 


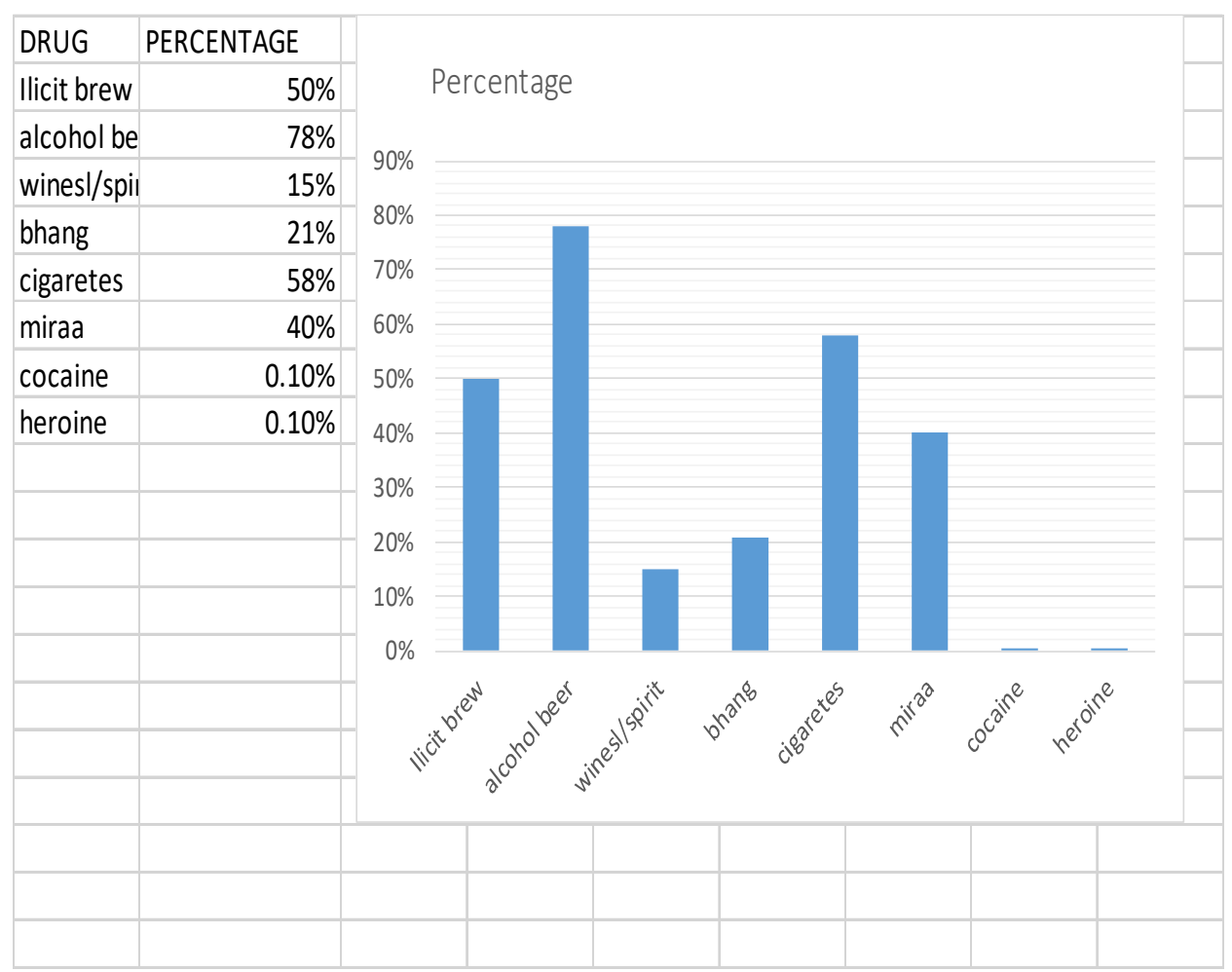

Figure 4.6: Showing commonly abused drugs among University students in Machakos town

The research findings revealed that alcohol was the most abused drug by University students in Machakos town. This could be because Alcohol is legal drug and also locally manufactured.

The findings agreed with those of NACADA (2004) who found out that alcohol, khat and tobacco were commonly abused drugs. This possibly reflects the overall current situation of drug abused by youth in the country, for example in NACADA (2004) reported that the National prevalence of drug abuse among youth was $60 \%$ for alcohol, $58 \%$ cigarette, $23 \%$ cannabis, $22 \%$ khat. The current scenario could be attributed by fact that Kenya has become a progressively significant transit point for drug destined for other countries such as Europe and North America. In addiction use of drugs such as Alcohol, Khat, Tobacco, is culturally, socially and legally acceptable in Kenya and those drugs are locally manufactured such factors have compounded the problem of substance abuse and dependence among the youth including students. The findings also agreed with studies done by Mueke (1980) in Machakos, Kirinyaga, Garrisa and Nairobi, who pointed out that Alcohol, Tobacco and Bhang were consumed mainly in Nairobi by girls and boys in secondary school.

\section{CONCLUSION}

\section{I. 2 Social factors influencing drugs abuse}

The findings of the study revealed that Social factors influence substance and drug abuse. Social factors occur when the actions or thoughts of an individual are changed by other individuals. Peer pressure was found to be the highest social factor which influences students (78.1\%) This is with agreement with United States report on drug abuse among young people, that most youngsters said that they used drug due to peer pressure especially those aged between 19-25 years (Conger \& Patterson, 2010).

Parental and other environmental factors were also found to influence students to substance and drug abuse (20\%), 22 out of 110 respondents gave parental and environmental factor as the reasons for taking drugs when presented with the two options. When asked who introduced them to drug abuse, some reported that their parents, other responded their siblings and other relatives. This evidence is in agreement with Conger and Patterson (2010) that parents who smoked and drink have a great influence on their children and they are 20 times likely to abuse drugs than those whom their parents don't abuse drugs.

What is the relationship between Gender and drug abuse universities in Machakos town?

The study concluded that there is significant differences between male and female students. The study revealed that Male students were more drug abusers than female students with $62.7 \%$ and $37.3 \%$ respectively. However the percentage of female students who drug abuse was on increase.

\subsection{Recommendations}

Based on findings of the study, the following recommendations are made: 
i) Governments should put in place measures of limiting easy access to drugs such as alcoholism, Tobacco and miraa (khat) this can be done reducing hours drugs consumption hour by enacting laws in the parliament such as infamous Mututho law. Other laws should be enacted.

ii) Institutions of learning like Universities should make their premise prohibited from consumption of any type drug. This could decrease the rate of peer influence if they do not see their colleagues take these drugs. Such notices like 'this institution is a drug free zone' should be elected in bill boards.

iii) Guidance and counseling should be established and emphasized and especially peer counseling. The emphasis should be put on universal approach which targets users and non-users some of whom may not be subjected to individual risk factors which encourage them to abuse drugs. Apart from universal prevention programmes the institutions also can use selective prevention programmes targeting youth considered to be at higher risk for substance use and abuse.

iv) Interventions progammes should be designed to halt abuse among those who already abuse drugs and Rehabilitate those who show signs of addiction. An educational programme used within the institutions should not aim at not only increasing knowledge and awareness about effects of drugs abuse, but should also aim at changing values, altitudes and beliefs which assumed to ultimately influence behavior as well as building social and personal skills.

\subsubsection{Recommendation for further research}

The researcher suggests that further researches should be carried out on;

i) Impact of parents abusing drugs on their children prevalence to drugs

ii) Peer counseling as determinant of reduced drug abuse among University students

iii) Impact of drug abuse on students on academic performance in University students.

iv) Investigate strategies used in addressing drug abuse.

v) All the commonly used drugs and substances noted in this study should be investigated to determine the extent and frequency of their use among the youth and why.

In addition, further research is needed to ascertain the relationship between the policies and drug and substance abuse among youth both in and out of school where it would make it easier to plan and implement the policy.

\section{REFERENCES}

Achola, R.(2013, July, 19). "Now Kaimenyi moves to probe unrest in schools" Daily Nation.

Adams, J. (2002). Resource Book for Drugs abuse Education, Washington DC: Government Press.

Aden, S.I. (2006). An investigation into the influence of Drugs on High school students with special reference to Wajir District, (Unpublished Theses) Kenyatta University.

Ameri, K.M. (2009).Organization and substance abuse in secondary school and implications for students discipline, a case of Tana River District,(Unpublished theses) University of Nairobi.

Aisto, F., Galizio, K.\& Gerard, D. (2011).Traditional approach to illegal behavior among youth, New York: Mc Grew Hill Companies.

Basangwa, D., Ndetei, M., Owuor, O.A.,Bawilahi,A. \&Gakinya, B. (2008). Hand book on prevention of drug and substance abuse in Kenya, Nairobi: NACADA.

Baunt, E. F.,Flakey, G. \&Balint, G. A.(2009).Khat a controversial plant,The middle EroupeanJournal of medicine, $12,19-20$ and 604-614.

Ciakuthi, B. (2002).Factors influencing students involvement in Drug Abuse in Secondary schools in Meru South and Meru East. (Unpublished thesis)Kenyatta University.

Chege, J. (March, 2002). Commonly abused drugs and their effects, Nairobi: Today Magazine.

Conger, J. J. \& Patterson, C. D. (2010).Adolescence and Youth: Psychlogical Development in changing world. $\left(5^{\text {th }}\right.$ Ed).New York: Addison, Wesley publishers.

Darat, P. (2012, Sept, $\left.5^{\text {th }}\right)$. Substance and Drug abuse and HIVAIDS. Nairobi: Daily Nation.

Davis, J.B. \& Stacey, B.(1972).Teenager and drinking, development study in Glascow, London:WHO Press.

Drug Abuse Warning Network (DAWN),(2006). Adolescent drug abuse in kenya: impact on reproductive health, Nairobi: New world printers.

Dishion, G., Kavanagh, J.,Schneiger, K., Nelson, L. \& Kaufman, J. (2002). Drugs and Youth Culture,London: WHO Press.

Fraenkel, J. R.\&Wallen, N. (2000) How to Design and Evaluate Research in Education, New York: McGraw Hill Companies.

Flisher, J. A. Ziervogel, C. F., Charlton, D.O., Leger, P. H. \& Robertson, A. (1993). Risk - Taking behavior of cape Pennisulla high school students, Drugs use.30 (83) 483- 485.

Gay, R. L. (1992). Educational research: competences for analysis and application, Ohio: Charlles E. MerrilPublishish Company.

Gershom, N. (2000). Hand book for primary \& secondary teacher's guidance in Drug dependence prevention Education,Nairobi: NACADA. 
Githinji, O. (2001, Dec, 10.)“'Drugs Destroying our Youth in East Africa,'” Nairobi:Standard,p.5-6

Goldstein, M. A. (2011). Adolescent substance abuse:The Mass general Hospital for Children Adolescent Medicine Handbook, New York: Springer Publications.

Grude, J. \&Morgan, M. (1996).Smoking, drinking and other drug use among DublinPost primary school students: Report for economic and social Research institute, Dublin: Vishram publishers.

Jerdrzejezak, M. (2005).Family and environmental factors of drug addiction among youth recruits. New York: Longman

Johnson, K. (2006).Drug use Drinking and smoking, National survey results from high school, college and young adult population in Maryland,New York: D.H. Publication.

Kaguthi, J. (2006).Drug Abuse in Nairobi Province and nationally, with specific reference to Education Institution, Nairobi:UNDCP.

Karechio, B. (2009). Drug Abuse in Kenya, Nairobi:Uzima Press.

Kariuki, D. (1988). Levels and patterns of drug addiction in Nairobi secondary schools, (Unpublished thesis) Kenyatta University.

Kisaki, J. N. (2012). Effects of drug abuse in secondary school case in Ijara and Garrisa district North eastern province,(Unpublished thesis) Kenyatta University.

Kimanthi, M. (2003).Levels of drug abuse in selected secondary school in Kitui district, (Unpublished thesis) Kenyatta University.

Kimiti, R. (2011). Teaching of the integrated topics on Drug Abuse among secondary school students in Machakos, District,(Unpublished thesis) Kenyatta University.

Kombo, D. K. \& Tromp D. I. (2006). An introduction Proposal and thesis writing, Nairobi: Pauline's publications.

Kothari, C. R. (1985). Research Methodology: Methods and techniques, New Delhi: WashwaPrakashan.

Kuntsche, E., Knibbe, R.,Gmel, G. \& Engels, R. (2005).Why do young people drink? A review of drinking motives, New York: Clinical Psychological Review.

Liddle, H. A. (2010). Treating adolescent substance abuse using multidimensional family therapy, New York: Guilford Press.

Lonah, K. (2013). "State alarmed over millions of youth wasted by drugs http://www.standardmedia.co.ke/lifestyle.

Madox, G. L. (2000). Drinking among teenagers: A sociological interpretation of alcohol use by college students, New Jersey: Rutgers centre of alcoholic studies.

Makwere, K. (1997 April, 5). Pubs hit hard by Alcohol Law. Daily Nation.

Mathison, S. \& Freeman, M. (1997). The logic of interdisciplinary studies: paper presented at the annual conference of American research association. Chicago:American Journal of Community Medicine vol. 30.

Melgosa, J. (2003).To Adolescent and Parents, Barcelona: Editorial safe Liz.Ministry of Health, (2010).Guidance on review of psychoactive substances interactional control, Nairobi: WHO press.

Ministry of Education science and Technology (MOEST), (2009). "Impact of drug abuse in secondary schools", Nairobi: Government press.

Mueke, J. (1980).Drug use and addiction among Kenyan school children. (Unpublishedresearch findings) Kenya Institute of Educatoin.

Mugenda, O. M. \& Mugenda, A .G, (1999). Research method, Nairobi: ACTS press. Muiruri, K. (2005). Commonly abused drugs and their effects, Nairobi:Today Magazine.

Musembi, O. (2004,July, 19). “Now saitoti moves to probe unless in schools', Nairobi: DailyNation.

Muchemi, R. (2012).Analysis of the factors that influence drug abuse among the students

InPrimaryTeachers, CollegeinCentralProvince.(Unpublished thesis) KenyattaU niversity.

Mwaniki, J. K. (2007).Adolescent drug abuse in kenya: Impact on reproductive health, Nairobi: New world printers.

Mursk, J. (2003). Report on the problems of drug among Kenyan Students in Secondary schools teacher colleges, A paper presented at the $4^{\text {th }}$ ICPA World congress, Nairobi.

Mwenesi, H. A. (1995). Rapid assessment study (RAS) of drug abuse in Kenya:A National report UNDCP, Nairobi: Uzima Press.

Nabunya, E. (1992). Prevalence of drug abuse and associated factors among secondary school students in Kampala, (Unpublishedtheses), Community medicine.Muhimili University College of health science, University of Dar es salaam. .

NACADA, (2010). National baseline survey on drugs, Nairobi: NACADA.

NACADA,(2011).Youth in Peril Alcohol and Drug abuse in Kenya,Nairobi: NACADA.

NACADA, (2013). Improve your awareness on youth and drug abuse, Nairobi: NACADA..

National Agriculture and livestock extension programme: (NALEP), (2011). Control of chronic and prevention of drug abuse, Englewood clifts: Printers Hall.

National Institutes for Alcohol Abuse and Alcoholism (NIAAA). (2009). A developmental 
perspectiveonunderagealcoholabuse. http://pubs.niaaa.nih.gov/publications/AA78/AA78.htm

Newcomb, M. D. \&Benter, P. M. (2004).Impact of Adolescent Drug use and social support on problems of young Adults: a longitudinal study, Journal of Abnormal Psychology, P.77-64-76.

National council of churches of Kenya (NCCK), (2011, Nov, 27).Drug abuse in secondary schools, "Nairobi: Daily Nation, P.8-9

Ndengwa, C. M. (2009).drug problem in schools a case in Murang'a District, (Unpublished thesis) Kenyatta University.

Ndetei, D. (2004). Lessons learned in Drug abuse and prevention: United Nation Office on drug and crime, London: WHO press.

Ndirangu, J. M. (2000). Youth in danger: hand book for Teachers, students, parents Pastors and community workers, Nairobi: Uzima press.

Ndungu,R.(2001).Secondary School Strikes:The Art of Blaming the victim, (Unpublished thesis) University of Nairobi.

Ng'enoh, D. K. (2005).Drug abuse and its influence on students leaving behaviour studyof econdary schools in Kericho districts,

(Unpublished thesis) University of Nairobi.

Nowinski, J. (1990). Substance abuse in adolescents and young adults, NewYork: W.W.Norton publishers.

Nyassi, D. M. (2006 May ,17). 'Drug abuse in school”, Nairobi: Daily Nation.

Oke, E. (1984). An introduction to social Anthropology:London: Macmillan EducationLtd Publishers.

Oken, A. M. (2010, Dec, 5). Advert misleading to youth. Nairobi: The standard.

Omolo, D. G. (2006).Levels, trends and patterns of drug addiction in secondary schools, (Unpublished theses) Kenyatta University.

Onyango, M. (2010 Nov, 21).“Horrifying drug specter now a reality’’.Nairobi: Dairy Nation.

Ogwell, O. (2013,Oct, 25). "Drug abuse in schools"'. Nairobi: The standard.

Orifa, J. J. (2004). Drug abuse and methods of prevention in mixed secondary school in Kiambu District, (Unpublished thesis): Kenyatta University.

Orodho, J. (2005). Essential of education and Social Sciences Research Method, Nairobi: Masola Publishers.

Patton, G. C. (2002). Cannabis use and mental health in young people: Cohort study on Adolescent gins in Kenya: A comparison of interviewing methods. British Medical Journal, vol. 325 - pp 1195-1198.

Pasche, K. (1970). With Guidance on the with review of psychoactive substances for interactional control, London: Gangle press

Pretrofesa, J.(1984).Counseling an introduction, Boston: Houghton Muslim company.

Pudo, M. W. (2001). Let's talk about drugs and Drug Abuse. Nairobi: Global BookmanPublishers.

Rongers, A.\&McCarthy, A. (1999).Drug Education prevention and policy, Vol. 6, United Kingdom: University College of London.

Robert, S. R. (2001.)Crime in Dar-es-salaam, Nairobi: UNCR.

Rowe, C. L. (2012). Family therapy for drug abuse: Review and updates 2003- 2012. Journal of Marital and Family Therapy, 38(1), 59-81.

Ruto,T. (2000,August, 24).Shocking statistics on drug in school,Nairobi: The Standard.

Scarpit, E. R. (2010). Drug and youth culture, London: Sage publication of Britain.

Schilit, R. (2008). Drug behavior: a sourcebook for the helping profession, New Delhi: Sage publications.

Schongergs, K. (2010). A guide for health professionals, Grove village: American academy of pediatrics.

Simiyu, S. K. (2000). Factors influences drug abuse in provincial schools in Nairobi province,(Unpublished Thesis) Kenyatta University.

Simonyi, G. (2011).Extent of drugs and drug abuse in selected public boarding secondary schools in Kakamenga District,(Unpublishedthesis) Kenyatta University,

Stanely, N. R. (2009).Factors influencing drug abuse in secondary schools in Kitui district,(Unpublished thesis) University of Nairobi.

Steinberg, L. (1989). Adolescent issues, New York:McGraw -Hill, Inc.

The Kenyascout association, (2008). Drug demand reduction: Education Programme Trainers Reference Manual, Just say No!,Nairobi: Kenya Scout Association.

Terry, Y. M.,Malley, P. M.\& Johnston, L. D. (2009). Reasons for drug use among American youth by consumption level, gender, and race/ethnicity: Journal of Drug Issues, 39(3), 677-714.

Umi, D.M.(2013, may 17).Drug abuse in school,. Nairobi Daily Nation: Kenya

United Nations, (2010).World Drug Report, on drug prevalence amongYouth, Great Britain: Oxford University Press.

United Nations, (2009).International Narcotics Control Report, New York: United Nations Publications.

United Nation office on drug and crime (UNODC), (2000),World drug report,Geneva: United Nations office on Drugs and Crime.. 
Waihenya, G. (2012, March, 15). ' Drugs Destroying our Youth in East Africa', Nairobi:The Standard, p.4-5.

Wambua, S. M. (2014, July, 20).Effects of drugs on youth in learning Institutions, Nairobi: The standard.

Wambuthi, K. N. (2003).Factors contributing to drug abuse in some selected public schools in Kiambu District.(Unpublished thesis) Kenyatta University.

Wanjala, E. N. (2006). The causes of drug use among secondary School Students in Kenya: A case study of secondary school in Nairobi, (Unpublished thesis) University of Nairobi.

Wanyoke, W. (2003).Understanding Youth and Family Issues from Christian perspective, Don Bosco: Printing Press.

Waweru, R.,Kamau, A. \&Matongo, J. (2011).Analysis of Alcohol consumption among University students, Nairobi: NACADA..

World Drug Report, (2004).UN office on control of chronic and prevention of drug abuse. Great Britain: Ball Press.).

Yonda, F.K . (2005).Adolescent risk Taking, Lond: Sage publications 